Yuliya G. Lavrikova ${ }^{a}$, Olga N. Buchinskaia ${ }^{\text {b) }}$, Ekaterina O. Wegner-Kozlova ${ }^{\text {c) }}$ a, b, c) Institute of Economics of the Ural Branch of RAS, Ekaterinburg, Russian Federation b, c) Research Financial Institute of the Ministry of Finance of the Russian Federation, Moscow, Russian Federation a) http://orcid.org/0000-0002-6419-2561, e-mail: lavrikova.ug@uiec.ru b) https://orcid.org/0000-0002-5421-2522

c) https://orcid.org/0000-0003-4182-6514

\title{
Greening of Regional Economic Systems within the Framework of Sustainable Development Goals ${ }^{1}$
}

Sustainable development was chosen by the United Nations as the key concept of the future in the 21st century, which led to the emergence of other economic concepts, such as green and blue economy, seen as contributing to the achievement of sustainable development goals (SDGs). In Russia, despite the ongoing processes of green transformation in some economic sectors and certain improvements in the green legislation and green finance, not all businesses and regions are ready to embrace sustainable development. This paper discusses two interconnected aspects of regional economic systems - their economic efficiency and environmental impact. The analysis focuses on the regions of the Ural Federal District and explores these regions' transition to sustainable development by looking at their eco-intensity. Methodologically, the study relies on the methods of analysis and synthesis, statistical, comparative and causal analysis. Conceptually, we use the theoretical framework of sustainable development as a point of departure for our discussion. The results have shown, on the one hand, a decrease in the industrial pressure on the natural environment, related primarily to the enhanced resource efficiency of certain industries. On the other hand, less effort is now invested into minimising the negative impact on the environment in Ural regions. We have also identified those areas of sustainable development that hold most promise in the Russian context. Our findings can serve as a basis for the strategies of regional sustainable development and may be used for further research on socio-environmental and economic sustainability.

Keywords: sustainable development, SDG, green economy, blue economy, greening, eco-intensity, Ural Federal District, eco-intensity, emissions, environment saving costs

\section{Acknowledgements}

The study has been conducted as part of the research project 'Key Issues of the Current International Agenda and the Participation of the Russian Federation in its Implementation (with a Focus on Specific Sustainable Development Goals)' implemented by the Financial Research Institute of Ministry Finance of Russia.

For citation: Lavrikova, Yu. G., Buchinskaia, O. N. \& Wegner-Kozlova, E. O. (2021). Greening of Regional Economic Systems within the Framework of Sustainable Development Goals. Ekonomika regiona [Economy of regions], 17(4), 1110-1122, https://doi.org/10.17059/ekon.reg.2021-4-5.

\footnotetext{
${ }^{1}$ (c) Lavrikova Yu. G., Buchinskaia O. N., Wegner-Kozlova E. O. Text. 2021.
} 


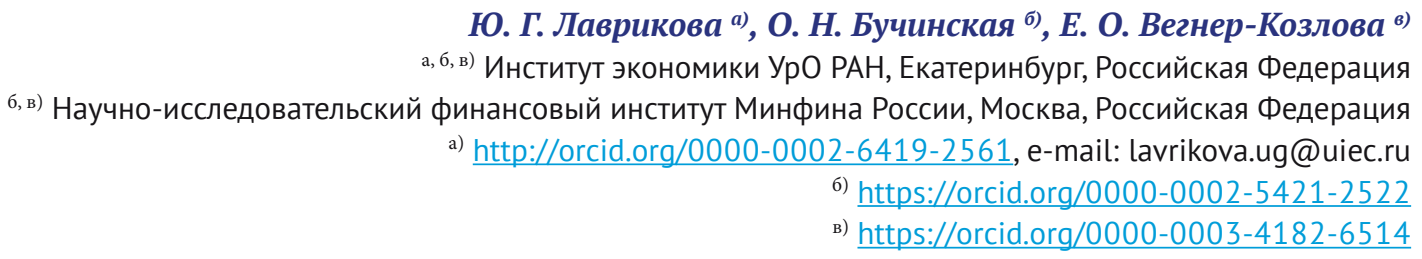

Ю. Г. Лаврикова ${ }^{\text {a) }}$, О. Н. Бучинская ${ }^{\text {б) }}$, Е. О. Вегнер-Козлова ${ }^{\text {() }}$

а, б, в) Институт экономики УрО РАН, Екатеринбург, Российская Федерация

6, в) Научно-исследовательский финансовый институт Минфина России, Москва, Российская Федерация

a) http://orcid.org/0000-0002-6419-2561, e-mail: lavrikova.ug@uiec.ru

6) https://orcid.org/0000-0002-5421-2522

в) https://orcid.org/0000-0003-4182-6514

\section{Экологизация региональных экономических систем в рамках целей устойчивого развития}

Устойчивое развитие было выбрано ООН в качестве главной концепции будущего в ХХІ в., что привело к появлению таких экономических направлений, как зеленая экономика и голубая экономики, способствующих достижению целей устойчивого развития (ЦУР). В России, несмотря на зеленую трансформацию отдельных отраслей экономики и определенные улучшения в области зеленого финансирования и экологического законодательства, не все предприятия и регионы готовы следовать принципам устойчивого развития. В данной статье рассматриваются два взаимосвязанных аспекта региональных экономических систем - их результативность и воздействие на окружающую среду. Объектом исследования послужили регионы Уральского федерального округа. Переход регионов к эколого-экономически сбалансированному типу развития был проанализирован на основе показателей экоинтенсивности. В работе применены методы анализа и синтеза, статистический, сравнительный и причинноследственный анализ. Методологическую базу исследования составили теоретические положения концепции устойчивого развития. Проведенный анализ продемонстрировал, с одной стороны, снижение негативной нагрузки на природную среду относительно результативности выбранных для исследования отраслей. С другой стороны, очевидно сокращение деятельности, направленной на минимизацию негативного воздействия на окружающую среду на Урале. Также были определены наиболее перспективные направления для достижения ЦУР в контексте национальных интересов РФ. Полученные результаты могут послужить основой для формирования региональных стратегий устойчивого развития, а также могут быть использованы в дальнейших исследованиях в области социо-эколого-экономической устойчивости.

Ключевые слова: устойчивое развитие, ЦУР, зеленая экономика, голубая экономика, экологизация экономики, эко-интенсивность, Уральский федеральный округ, экоинтенсивность, выбросы, затраты на сохранение окружающей среды

\section{Благодарность}

Статья подготовлена в рамках научного исследования «Актуальные вопросы международной повестки дня и участие Российской Федерации в ее реализации (на примере отдельных иелей устойчивого развития)» проводимого НИФИ Минфина России.

Для цитирования: Для цитирования: Лаврикова Ю. Г., Бучинская О. Н., Вегнер-Козлова Е. О. Экологизация региональных экономических систем в рамках целей устойчивого развития // Экономика региона. 2021. Т. 17, вып. 4. С. 11101122. https://doi.org/10.17059/ekon.reg.2021-4-5.

\section{Introduction}

In the twenty-first century, sustainable development has come to be generally acknowledged as the core concept for envisioning the future. Greening economic development is a process that encompasses all regions of the world and has already become a strategic priority for many countries. The majority of countries have now affirmed their commitment to the goals of improving resource efficiency and reducing the negative effects of economic growth on the environment [1]. The search for ways to reconcile the objectives of environmental policies and economic development is now gaining currency.
Sustainable development is seen as a global challenge to be handled on the international level and it also determines the goals for mutually beneficial cooperation between the countries (both economic and socio-political) in the interests of the entire world community. The concepts of green and blue economy and of green growth set the priorities and establish a long-term vision supported by national legislations and policies. What they share is the goals of enhancing energy efficiency and promoting the use of renewables, reduction of waste generation through prevention, reduction, recycling and reuse, promotion of the greening of the industrial sector and more sustainable 
agriculture, setting the stage for global food systems transformation, and development of medical technologies.

Among other things, sustainable development goals (SDGs) prioritise active involvement of businesses, which, according to the authors of the renewed UN Agenda, may play a key role in the achievement of the SDGs. It is, therefore, important to 'gain a clearer understanding of the expectations of more active businesses and take into account the commercial benefits of sustainable development as well as the new conditions resulting from the increase in competitiveness' $[2,3]$. The participation of companies in sustainable development will inevitably affect the general business climate in international markets. For businesses it will mean, on the one hand, new requirements and restrictions but, on the other, new opportunities and competitive advantages as businesses will be able to ensure their stable long-term development and meet the expectations of the key stakeholders. The current global trends have brought environmental priorities into companies' agendas: sustainability has come to be seen as a major goal rather than a minor addition to separate projects. SDGs have thus come to be seen by companies not only as a threat but also as a way to gain a competitive advantage and as an essential element of their business strategies.

Unfortunately, in Russia not all businesses are willing and ready to embrace sustainability. To encourage business participation, in particular, to foster the transition of companies to a green and blue economy, the government will have to tackle the following barriers:

- organisational and legal barriers;

- cost-related barriers;

- cultural and historical barriers;

- geographical and natural barriers.

Therefore, it is necessary to search for efficient ways of reconciling sustainability and economic growth. A pertinent task to be addressed is the evaluation of the national economic system both from the perspective of its productivity and from the perspective of its environmental impact. Such evaluation will be able to shed light on the role of business in sustainable development and the priority areas for business participation on the national level.

\section{Theoretical Framework}

Sustainable development goals first attracted the attention of theoretical economists in the second part of the twentieth century. The Limits to Growth (LTG), a report published by the MIT team in 1972 and based on computer simulation, ex- plored the exponential economic and population growth with a finite supply of resources. The report was commissioned by the think tank called the Club of Rome and marked the beginning of the international debate on sustainable development [4, p. 102-103]. Since then, a diversity of related concepts and approaches have evolved in economic theory.

Within the Schumpeterian approach, for example, the leading role in the achievement of SDGs is played by the innovative entrepreneur, able to push the economy forward by overcoming the current constraints through cutting-edge research and human capital development. In the long term, the Schumpeterians adhere to the so-called green techno-economic paradigm (TEP), which is understood as the increasing 'greening' of the technological sphere at all stages of product development [5]. For instance, Mathews [6] discusses the emergence of the new generation of smart green platforms that will open up new opportunities for business development. However, there is a risk that these trends will exacerbate the existing inequality between developed and developing countries [7].

Proponents of the neo-classical model see the solution to the problem of environmental sustainability in monetary valuation of environmental impacts and their internalisation; in other words, the valuation of environmental damage becomes a part of the pricing mechanism. In this case, the environmental damage will be reduced to the equilibrium level where the marginal costs of the use of non-renewable resources will be equal to the marginal profit gained from their use [8].

The 'eco-sustainable framework' developed within post-Keynesian economics focuses on the stimulation of the cumulative effective demand for environmental-based goods and services and on setting ecological rules that will redirect capital investment to resource-saving technologies with long-term carrying capacities [9]. Instruments of state regulation may include developing systems of taxes and tax incentives, cancelling all fossil fuel subsidies [10], creating a buffer reserve of non-renewable resources [11], reducing labour intensity and cutting working hours [12].

Green Keynesianism, which emerged in the twenty-first century, was the reaction of the neo-Keynesian movement to the rise of the environmental agenda. From the perspective of Green Keynesianism, investments in green infrastructure should at least be able to maintain the same level of welfare after the economy collapses due to resource exhaustion. These investments are expected to pay back the debt acquired to finance 
them [13]. Environmental economists seek to develop economic valuation techniques for environmental assessment. For instance, Constanza identifies three types of value of ecosystem services: efficiency, which stands for willingness-to-pay for a certain product or service; fairness, which reflects the interests of the public and the community and is used to measure the value of public goods; and sustainability, which means the valuation of the physical, chemical and biological role the services play in the long-term operation of the global ecosystem [14].

In Russia, no universal approach to studying the problems of the green economy has yet been developed. Most Russian studies focus on the practical applications of green economy principles in the national context. For example, Bochko [15] explores the implementation of green economy principles in Russian industries and outlines the most urgent environmental problems of the Ural region [16]. Much attention is given to the implementation of the model of closed-loop economy: for example, Pakhomova, Richter and Vetrova examine the application of these principles in the Russian context [17] (see also Richter and Vetrova [18]). Valko [19] considers business models used in a closed-loop economy. Mirzekhanova discusses the questions related to the green economy that have a significant impact on the establishment of the so-called advanced development zones [20]. Funding of the Russian green economy and in particular the national climate policy are analysed by Yakovlev, Kabir and Nikulina [21]. They argue that the Russian model of the climate policy is still at an early stage of development; its current aim is to address the problems of greenhouse gas emissions and adaptation of the Russian economy to climate change. Kabir [22] considers state and private financing of the green transition and makes a conclusion that the Russian government should be taking a more active part in environmental problem-solving.

Thus, both the theoretical and practical aspects of SDGs implementation are of prime importance to the modern global community in general and to Russia in particular. As the above-described theories show, the economic aspects of the environmental SDGs are among the top priorities of the modern world.

\section{Methodology}

Our analysis focuses on the regions of the Ural Federal District: Kurgan, Sverdlovsk, Tyumen, Chelyabinsk oblasts, Khanty-Mansi Autonomous District - Yugra (KhMAD-Yugra) and YamaloNenetsk Autonomous District (YNAD). To evalu- ate the progress of these regions' transition to a more sustainable type of economic development, we selected the indicators of eco-intensity adjusted to gross regional product (GRP) as a sum of gross value added at basic prices. In this context, eco-intensity is understood as the amount of natural resources used per unit of output ${ }^{1}$. Our study relies on the following methods: methods of analysis and synthesis, statistical method, method of comparative analysis and causal analysis.

\section{Results}

\section{Transition to Green Economic Systems in Pursuit of the SDGs}

The UN reports emphasise that the transition to sustainable development should rely primarily on the transition to a green economy. In this study, we follow the UNEP's approach and define green economy as an economic model that is aimed at improving human well-being and social equity, while significantly reducing environmental risks ${ }^{2}$. Within a somewhat narrower approach, green economy is seen to encompass the types and results of economic activities that, along with industrial modernisation and enhancement of production efficiency, help raise the living standards and improve the living environment [23].

Another pivotal concept that needs to be considered is that of blue economy. Like the concept of green economy, which goes beyond the green eco-system, the blue economy is not limited solely to the marine eco-system. Moreover, in the way similar to the green economy, the blue economy implies new ways of designing business: using the resources available in cascading systems, where the waste of one product becomes the input to create a new cash flow. The concept of blue economy is much broader than the 14th SDG focused exclusively on the preservation and rational use of water resources. It should be noted that the tasks included into the SDG 14 may also be related to other issues besides those of sustainable water use [24].

\footnotetext{
${ }^{1}$ Making sustainability accountable: Eco-efficiency, resource productivity and innovation. Topic report No 11/1999// Proceedings of a workshop on the occasion of the Fifth Anniversary of the European Environment Agency (EEA) 28 30 October 1998 in Copenhagen. Retrieved from: https://www. eea.europa.eu/publications/Topic_report_No_111999/download (Date of access: 22.08.2021).

2 Towards a Green Economy: Pathways to Sustainable Development and Poverty Eradication//A Synthesis for Policy Makers. Synthesis. Nairobi: UNEP, 2011. Retrieved from: http:// www.unepcom.ru/wdownloads/ger_synthesis_ru.pdf (Date of access: 10.05 .2021$)$.
} 
The SDGs directly connected to the development of a sustainable blue economy are also aligned with other SDGs such as the following [25]:

1. SDG 14 (Life below water)

2. SDG 17 (Partnership for the goals)

3. SDG 16 (Peace, justice and strong institutions)

4. SDG 15 (Life on land)

5. SDG 12 (Responsible consumption and production)

According to the OECD forecast, 'despite the current slowdown in economic activity, demands on marine resources for food, energy, minerals, leisure and other needs of a growing global population will persist'".

Since economy is a part of a multi-factor natural and social system consisting of interconnected components whose evolution is not always easy to predict [26], the areas of development of green and blue economy measured through target indicators are determined by the SDGs for the integration of environmental, social, and economic concerns (Table 1).

Greening the economy should be considered as one of the key conditions of sustainable socio-economic development of territories. In practice, however, both the implementation of green economy principles and the evaluation of its outcomes should take into account the regional context. While sustainable development is undoubtedly a global goal, projects based on green economy principles emerge irregularly across regions and remain uncoordinated. This situation can be explained by the complexities inherent in the organisational, administrative, geographical, cultural and other aspects of interregional cooperation. Therefore, the indicators of the green economy should reflect the actual situation in regions and the specific environmental problems they are facing.

The UN's concept of sustainable development provides a viable opportunity for Russia to adapt in a systematic fashion to the global agenda because Russia is already a highly developed country ${ }^{2}$.

\footnotetext{
${ }^{1}$ The transition to a sustainable ocean economy is a global imperative / OECD iLibrary. Online library of the Organisation for Economic Cooperation and Development (OECD). Retrieved from: https://www.oecd-ilibrary.org/sites/7d03e22b-en/index. html?itemId=/content/component/7d03e22b-en (Date of access: 27.05.2021).

2 Bobylev, A. N. \& Grigoriev, L. M. (Eds.). (2016). The UN's Sustainable Development Goals and Russia/The UN's Sustainable Development Goals and Russia/ Report on the Human Development in the Russian Federation for 2016. Moscow: Analytical Centre under the Government of the Russian Federation, 2016. Retrieved from: https://ac.gov.ru/ files/publication/a/11068.pdf (Date of access: 17.05.2021)
}

\section{Evaluation of the 'Eco-Intensity' of Regions in the Ural Federal District}

In Russia, the most polluting types of economic activity are the extractive industry; manufacturing; electricity, gas, steam and air conditioning supply; water supply, sewerage, waste collection and disposal, pollutant discharge elimination. As the case of Sverdlovsk region illustrates (see Table 2), the contribution of these types of economic activity to air pollution is over $96 \%$; to waste generation, $98.75 \%$; and water use, $96.1 \%$.

The share of these types of economic activity in GRP of the Ural Federal District is quite substantial (see Fig.1).

If we look at the negative environmental impact of these industries, the need to ensure the compliance of the Russian business sector with the SDGs 12, 13, 14 and 15 becomes obvious.

The performance of the economic system and its environmental impact can be evaluated from the perspective of eco-intensity. Eco-intensity may be seen as 'one of the possible indicators to evaluate a region's transition to a more sustainable and balanced type of economic development' [27].

To evaluate the eco-intensity of the Ural Federal District, we selected the following indicators: 'Freshwater use', 'Volume of waste discharged to water', 'Emissions into the atmosphere of pollutants and other substances from stationary sources', 'Production and consumption waste generation'. These indicators were adjusted for the share of the most polluting economic activities in GRP (mineral extraction, manufacturing, electricity, gas, steam and air conditioning supply, water supply, sewerage, waste collection and disposal, pollutant discharge elimination). The dynamics of the eco-intensity of Ural regions is shown in Figures 2, 3, 4 and $5^{3}$.

The available data show that in the given period, there was a decrease in the 'Pollution intensity' in such indicators as 'Freshwater use' and 'Production and consumption waste generation' in all the regions, except for Chelyabinsk region. In the indicators 'Volume of waste discharged to water' and 'Emissions into the atmosphere of pollutants and other substances from stationary sources', the dynamics was negative in all the regions.

For a more comprehensive analysis of eco-intensity, we added such indicators as 'Capturing of air pollutants emitted from stationary sources', 'Environmental protection expenditures', and 'Investment into main capital aimed at environ-

\footnotetext{
${ }^{3}$ Compiled by the authors by using the data from: The Urals in Figures. 2021: Statistical yearbook. (2021). Sverdlovskstat. Kurgan, 164.
} 
Green and blue economy and the SDGs*

\begin{tabular}{|c|c|c|c|c|}
\hline $\begin{array}{c}\text { Areas } \\
\text { of SDGs }\end{array}$ & SDGs & Indicators & $\begin{array}{c}\text { Areas } \\
\text { of SDGs }\end{array}$ & Indicators \\
\hline 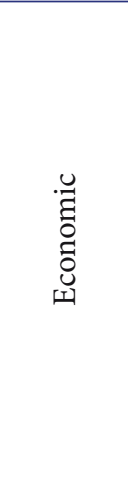 & $\begin{array}{l}\text { 1. (No poverty) } \\
\text { 2. (Zero hunger) } \\
\text { 3. (Good health and } \\
\text { well-being) } \\
\text { 6. (Clean water and } \\
\text { sanitation) } \\
\text { 7. (Affordable and clean } \\
\text { energy) } \\
\text { 8. (Decent work and } \\
\text { economic growth) } \\
\text { 9. (Industry, innovation } \\
\text { and infrastructure) }\end{array}$ & $\begin{array}{l}\text { Economic growth in the green sectors } \\
\text { Structure of the green economy } \\
\text { Sector of green products and services as } \\
\% \text { of GDP } \\
\text { Exports of green products and services as } \\
\% \text { of GDP } \\
\text { Imports of green products and services as } \\
\% \text { of GDP } \\
\text { Prices of the key green products } \\
\text { Energy pricing } \\
\text { Water pricing }\end{array}$ & 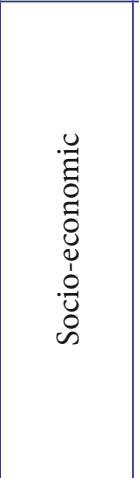 & $\begin{array}{l}\text { Labour productivity in the } \\
\text { green sector } \\
\text { Cost of labour in the green } \\
\text { sector } \\
\text { Green jobs (employment in the } \\
\text { green economy sectors) } \\
\text { The share of financial flows } \\
\text { constituting green growth }\end{array}$ \\
\hline 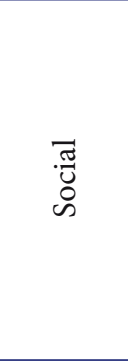 & $\begin{array}{l}\text { 4. (Quality education) } \\
\text { 5. (Gender equality) } \\
\text { 10. (Reduced inequality) } \\
16 \text { (Peace, justice and } \\
\text { strong institutions) } \\
17 \text { (Partnerships for the } \\
\text { goals) }\end{array}$ & $\begin{array}{l}\text { Labour market in the green sectors of } \\
\text { economy } \\
\text { Unemployment } \\
\text { Socio-demographic indicators } \\
\text { Demographic growth, population } \\
\text { composition and density } \\
\text { Life expectancy } \\
\text { Gini coefficient } \\
\text { Access to education and levels of education }\end{array}$ & 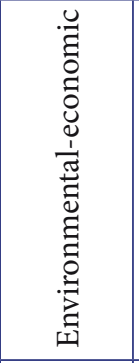 & $\begin{array}{l}\text { Amount and structure } \\
\text { of tax revenue related to } \\
\text { environmental protection } \\
\text { GDP per unit of } \mathrm{CO}_{2} \text { emissions } \\
\text { Profit per unit of materials } \\
\text { (abiotic, biotic) } \\
\text { Negative environmental } \\
\text { impact per unit of GDP }\end{array}$ \\
\hline 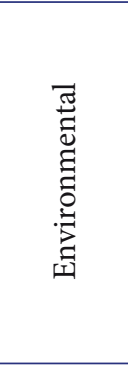 & $\begin{array}{l}11 \text { (Sustainable cities and } \\
\text { communities) } \\
12 \text { (Responsible } \\
\text { consumption and } \\
\text { production) } \\
13 \text { (Climate action) } \\
14 \text { (Life below water) } \\
15 \text { (Life on land) }\end{array}$ & $\begin{array}{l}\mathrm{CO}_{2} \text { emissions } \\
\text { Energy intensity } \\
\text { Share of renewables used for energy } \\
\text { generation } \\
\text { Environmental Performance Index } \\
\text { Freshwater resources } \\
\text { Forest area } \\
\text { Fish stock } \\
\text { Mineral reserves } \\
\end{array}$ & 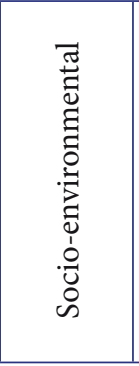 & $\begin{array}{l}\text { Reduction in life expectancy } \\
\text { caused by environmental } \\
\text { pollution } \\
\text { Population exposure } \\
\text { to pollution and other } \\
\text { environmental problems } \\
\text { Share of population without } \\
\text { access to safe drinking water }\end{array}$ \\
\hline
\end{tabular}

* Compiled by the authors.

Table 2

Impact of economic activities on environmental pollution (based on the data for 2019)*

\begin{tabular}{|l|c|c|c|}
\hline \multirow{2}{*}{\multicolumn{1}{c|}{ Type of economic activity }} & \multicolumn{2}{c|}{ Share in the total amount of pollution: } \\
\cline { 2 - 4 } & $\begin{array}{c}\text { Release of raw or improperly } \\
\text { treated wastewater into surface } \\
\text { water bodies, \% }\end{array}$ & water use, \% & $\begin{array}{c}\text { waste } \\
\text { generated, \% }\end{array}$ \\
\hline Mineral extraction & 22,30 & 8,00 & 84,55 \\
\hline Manufacturing & 25,38 & 35,76 & 9,80 \\
\hline Electricity, gas, steam and air conditioning supply & 2,45 & 19,97 & 3,16 \\
\hline $\begin{array}{l}\text { Water supply, sewerage, waste collection and disposal, } \\
\text { pollutant discharge elimination }\end{array}$ & 48,40 & 32,40 & 1,21 \\
\hline Other types of economic activity & 1,47 & 3,87 & 1,28 \\
\hline In total for Sverdlovsk region & 100,00 & 100,00 & 100,00 \\
\hline
\end{tabular}

* Compiled by the authors by using the data of the state report 'On the Current State and Preservation of the Environment in Sverdlovsk Region in 2019'.

mental protection and rational use of natural resources' adjusted for the share of the most polluting industries in GRP to evaluate the effectiveness of regional environmental policies (Figures 6, 7, 81).

\footnotetext{
${ }^{1}$ Compiled by the authors by using the data from: The Urals in Figures. 2021: Statistical yearbook. (2021). Sverdlovskstat.
}

An important trend that should be noted is the decline in the indicator 'Capturing of air pollutants emitted from stationary sources' in all the regions. Overall, there has been a general fall in the expenditures on environmental protection as per-

Kurgan, 164. 


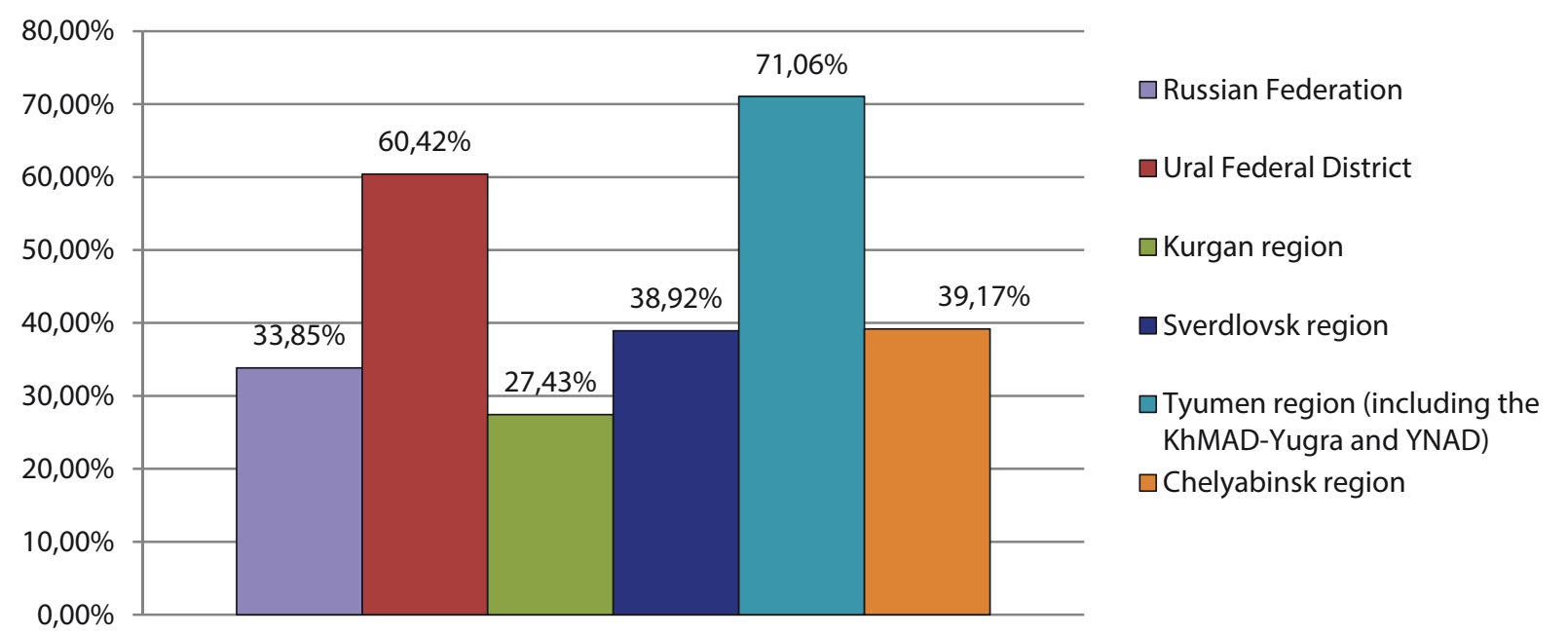

Fig. 1. Share of the most polluting types of economic activity in GRP of the Ural Federal District

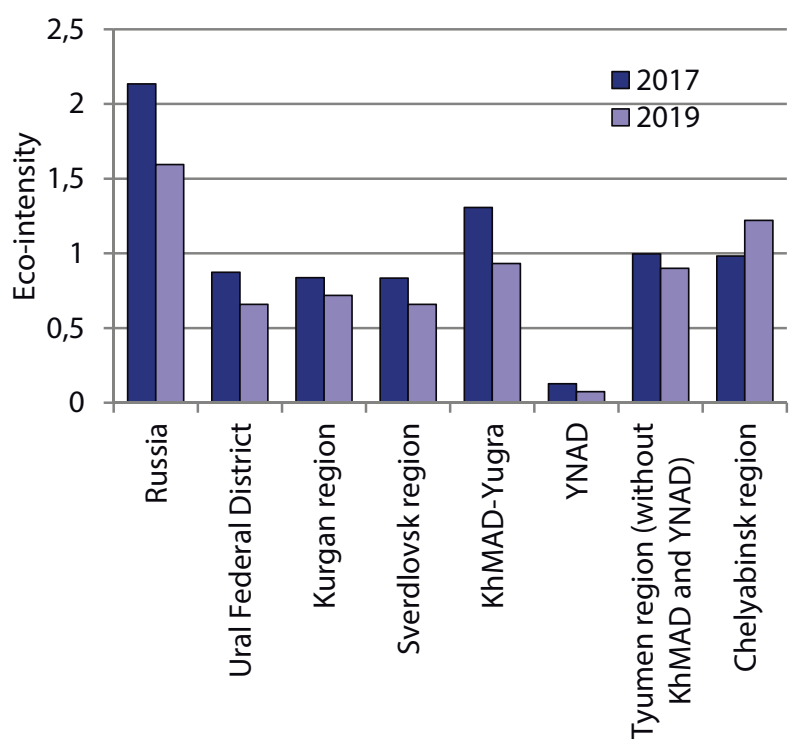

Fig. 2. Freshwater use $m 3 /$ ths rbs

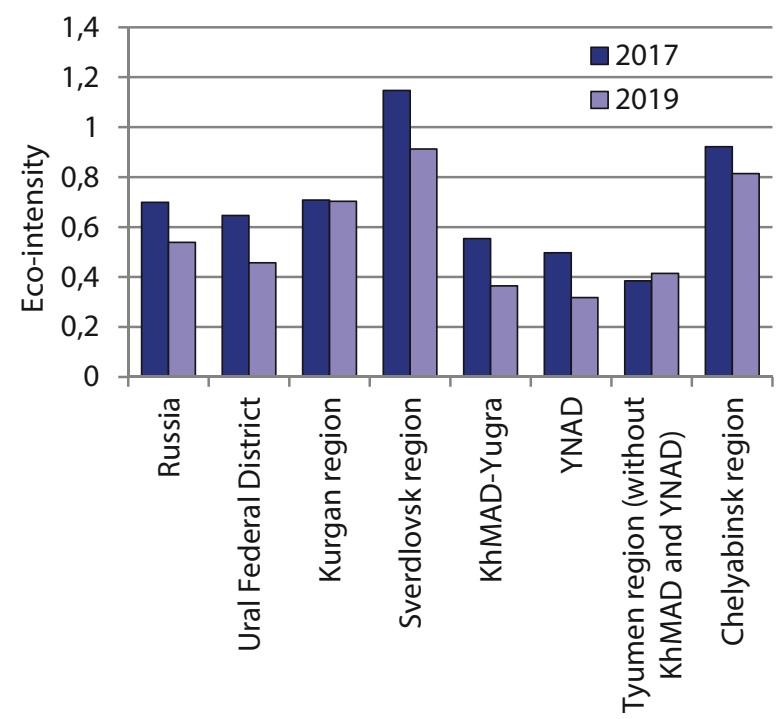

Fig. 4. Emissions into the atmosphere of pollutants and other substances from stationary sources, tons $/ \mathrm{m} / \mathrm{n}$ rbs

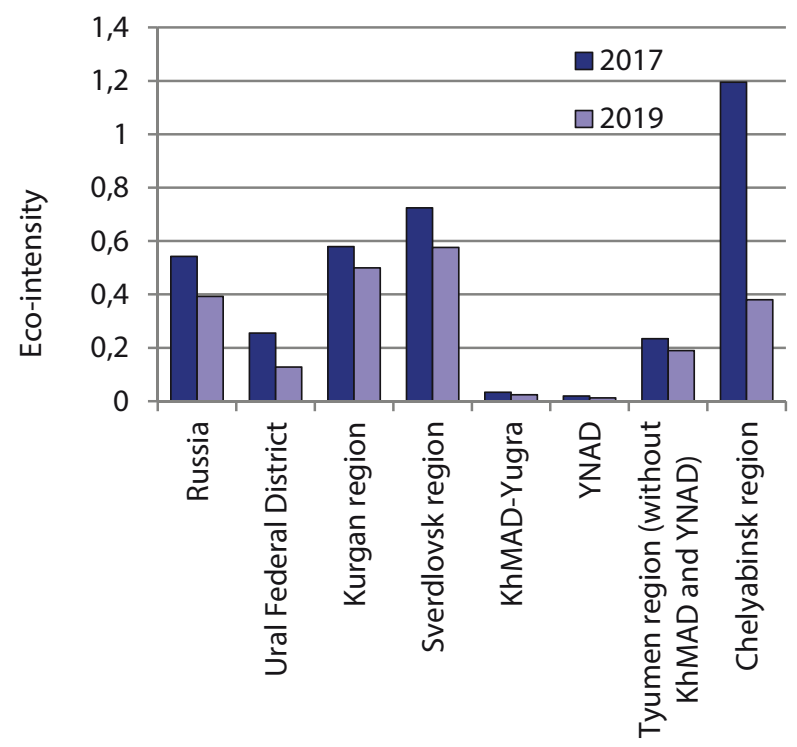

Fig. 3. Volume of waste discharged to water, $m 3 /$ ths $r b s$

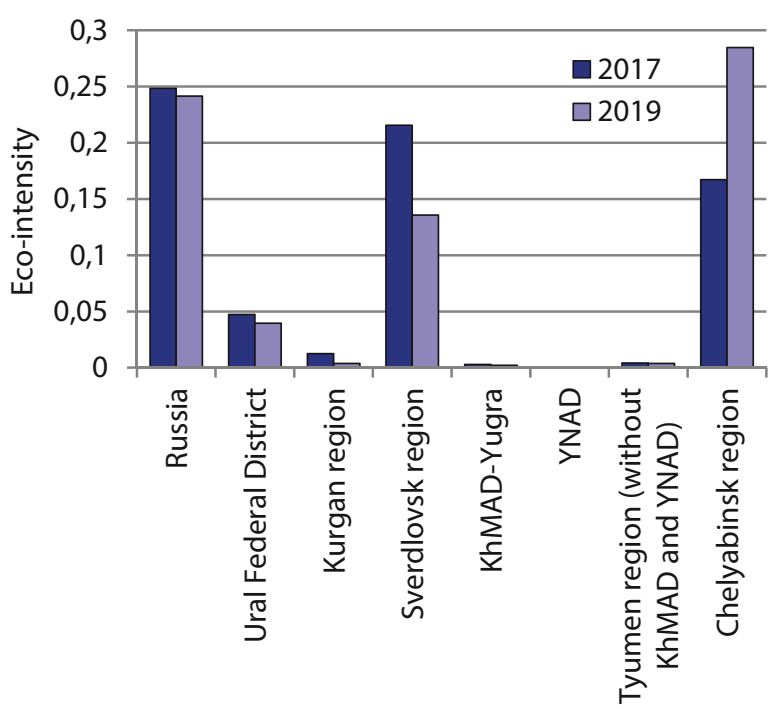

Fig .5. Production and consumption waste generation tons/ ths rbs

www.economyofregion.com 


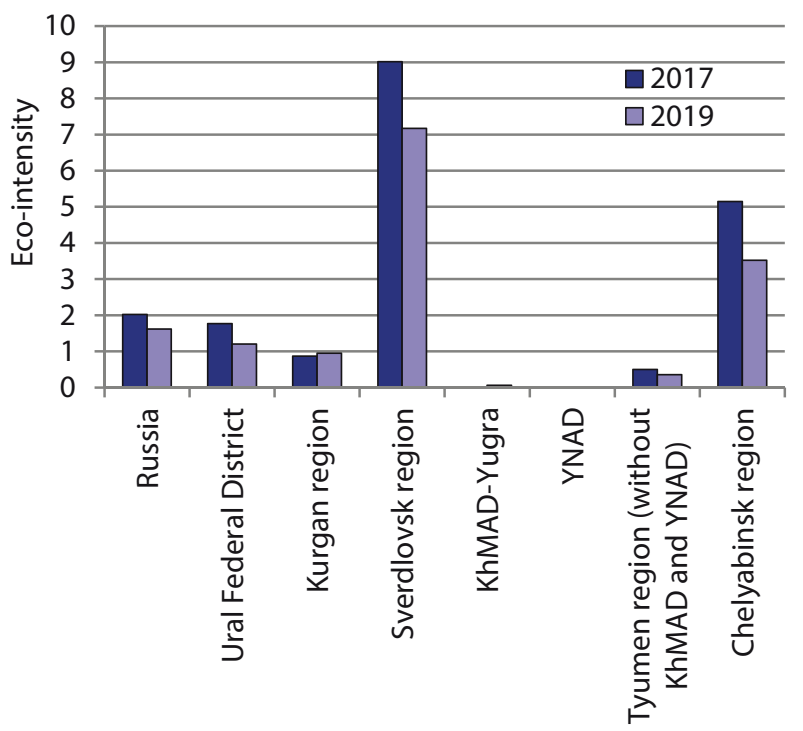

Fig. 6. Capturing of air pollutants emitted from stationary sources, tons $/ \mathrm{m} / \mathrm{n}$ rbs

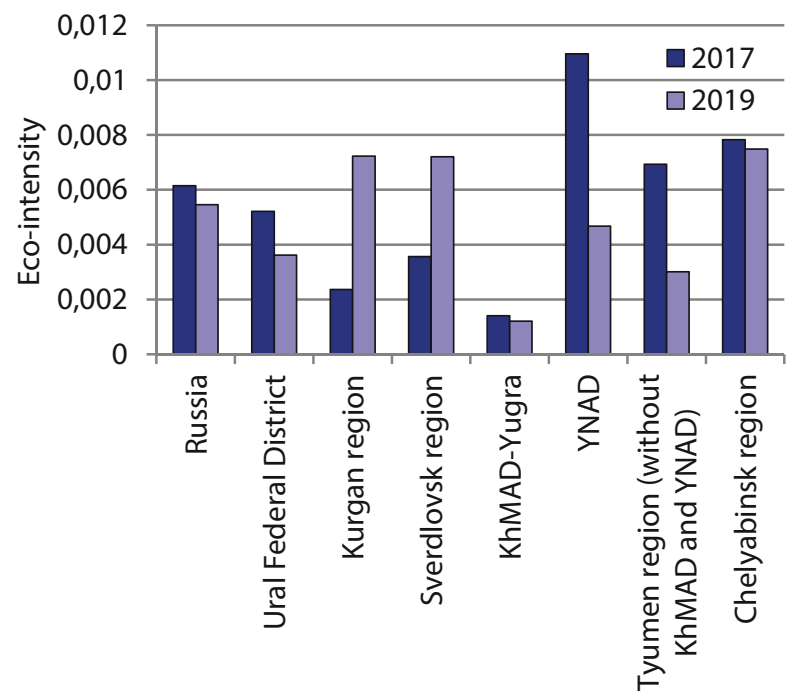

Fig. 8. Investment into main capital aimed at environmental protection and rational use of natural resources, rbs

centage of GRP across the Ural Federal District, in particular in the Khanty-Mansi Autonomous District - Yugra, Yamalo-Nenetsk Autonomous District and in Tyumen region. On the national level, the dynamics is generally positive.

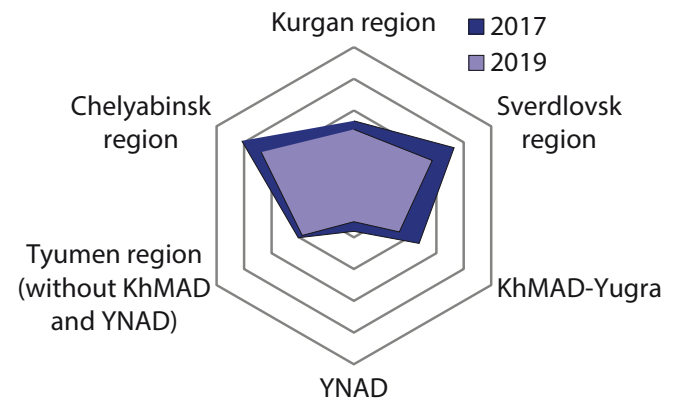

Fig. 9. Average eco-intensity of the negative environmental impact (compiled by the author)

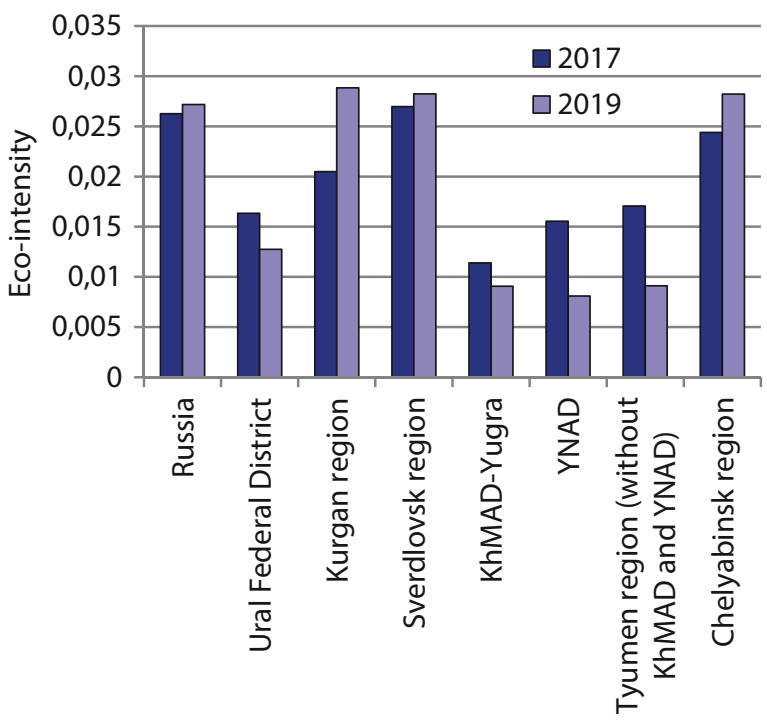

Fig. 7. Expenditure on environmental protection, rbs

Sverdlovsk, Kurgan, and Chelyabinsk regions also demonstrate a positive dynamics. The indicator 'Investment into main capital aimed at environmental protection and rational use of natural resources' grew only in Kurgan and Sverdlovsk regions in the given period.

The average data calculated as arithmetic mean values demonstrate, on the one hand, a decrease in the negative environmental impact per unit of GRP (Fig. 9) and, on the other, a decrease in the efforts of regional governments and businesses to minimise this negative impact (Fig. 10).

As Figure 9 illustrates, eco-intensity in the given indicators is decreasing in all Ural regions. Figure 10, however, shows that in the same period there was also a decline in the indicators reflecting the efforts to minimise the negative environmental impact.

Obviously, it is possible to reduce the negative environmental impact by using green technologies, which require a more detailed analysis of environmental protection expenditures.

To analyse the current environmental expenditures, the related indicators were adjusted for GRP measured as a sum of gross value added at basic

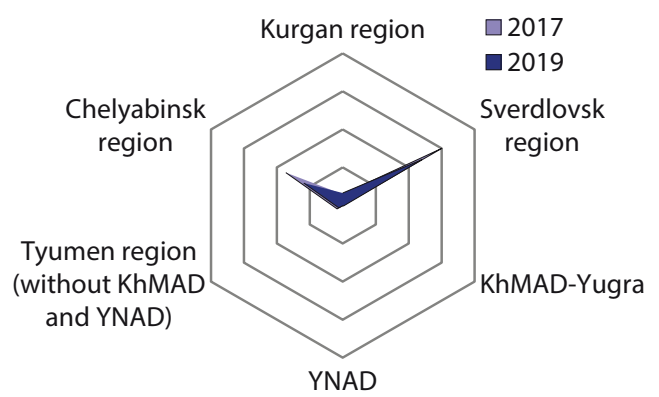

Fig. 10. Average indicator levels reflecting the efforts to minimise the negative environmental impact 10 


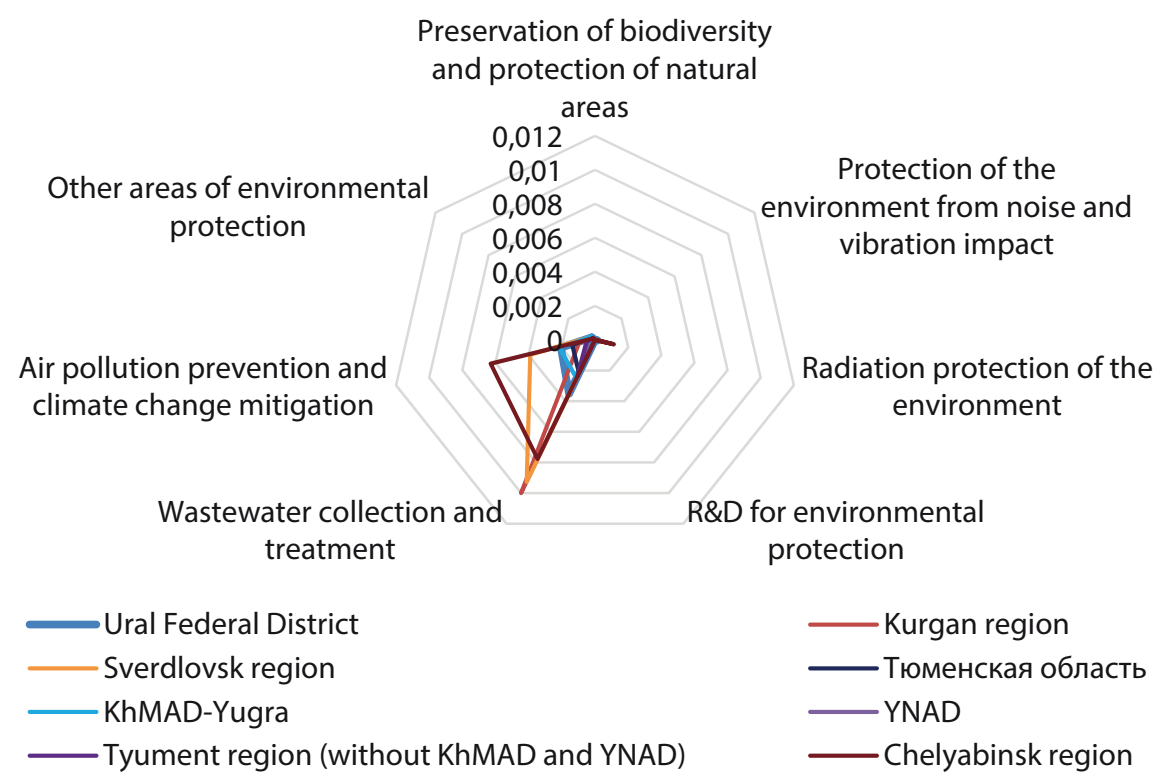

Fig. 11. Distribution of environmental protection expenditures per unit of GDP by type of economic activity, 2019 (compiled by the authors by using the data from Rosstat. Retrieved from: https://showdata.gks.ru/report/278028/ (Date of access: 15.06.2021); Unified Interdepartmental Statistical Information System. Retrieved from: https://fedstat.ru/indicator/59448 (Date of access: 15.06.2021))

prices in mineral extraction, manufacturing, electricity, gas, steam and air conditioning supply, water supply, sewerage, waste collection and disposal, pollutant discharge elimination. The resulting indicator shows the current environmental expenditures per rouble of profit from the most polluting economic activities.

Figure 11 shows that the regions that spend the most on environmental protection per unit of GRP are Chelyabinsk (0.015) and Sverdlovsk (0.014) regions. The Yamalo-Nenetsk Autonomous District along with Tyumen region (the KhAD and YNAD excluded) spend the least -0.002 and 0.003 respectively. There are also significant disparities in the distribution of environmental expenditures: while most of the funds are spent on the purification of wastewater and air, other types of the adverse environmental impact are given much less attention. For instance, Sverdlovsk and Chelyabinsk regions allocate funds to ensure radiation safety while other regions, for example, Kurgan region, are spending negligible amounts on radiation safety, if at all. Interestingly enough, although Sverdlovsk region has the Beloyarsk Nuclear Power Station, it spends less than Chelyabinsk region $-649,468$ thousand roubles against 687,525 thousand roubles. In terms of biodiversity expenditures, the Yamalo-Nenetsk Autonomous District ranks the highest $-39,961$ thousand roubles. Nevertheless, if we look at spending per unit of GDP, we will see that the leader is Sverdlovsk region, whose expenditure level is 1.9 times higher than that of the YNAD. The worst results in terms of biodiversity protection both in relative and absolute terms are displayed by Chelyabinsk region (305 thousand roubles or 0.000000504 roubles per rouble of GDP). Nevertheless, this region ranks high among other Ural regions in terms of protection of the environment from noise and vibration impact ( 0.0001 roubles per rouble of GRP). This situation is alarming especially in view of the fact that this region's research and development (R\&D) expenditures for environmental protection are extremely small. To put this into context, the Khanty-Mansi Autonomous District spends 0.000004998 per rouble of GRP or 17,425 thousand roubles in absolute terms on $R \& D$ for the reduction in the negative anthropogenic effects on the environment. Similarly, Kurgan region spends next to nothing on $R \& D$ while the expenditures on $R \& D$ in Sverdlovsk and Chelyabinsk regions are 0.0000016 and 0.0000013 per rouble of GRP respectively. Such structure of expenditures signifies the neglect of environmental issues in Ural regions, which appear to be left lagging behind the federal government's agenda on sustainable development.

Our analysis of the indicators adjusted to the economic performance of industries has shown that regional businesses are generally not interested in sustainable development, for example, they put little effort into minimising their negative environmental impact. Moreover, there has been a decline in expenditures on environmental protection per unit of GRP. 


\section{Key Areas of the Green Economy and Sustainable Development of the Ural Regions}

The commonly accepted key areas of the green economy are as follows [26]:

- Development of resource-efficient production and sustainable manufacturing and energy security;

- Modernisation of industrial infrastructure for low-emission production and environmental protection;

- Development of green investment and eco-innovation;

- Development in the sphere of construction (smart cities, eco-cities);

- Development of eco-tourism;

- Development of low-emission, energy-efficient transport (hybridisation and electrification).

However, it is necessary to take into account specific regional contexts: for example, for the regions with highly developed industries and construction, it may be more productive to focus on implementing eco-friendly technologies in their most polluting industries such as metallurgy, chemistry, petroleum chemistry, petroleum processing, and heavy engineering. Regions abundant in mineral resources and forests should prioritise greening in the use of these resources [28]. The industrial specialisation of the Ural Federal District means the priority of such questions as air and water pollution, production and consumption waste generation (see Figures 3, 4, 5). These areas should be considered as vital for the development and implementation of sustainability practices.
Modern industrial complexes generate large amounts of waste, which requires considerable planning and management efforts to reduce and utilise waste as well as to conserve and recover resources. Current waste management strategies give top priority to preventing waste rather than waste disposal or processing [29]. In the green economy context, the key areas of waste utilisation include the following: reuse of waste as ballast materials, clay blankets, production of wastebased biocover materials, construction materials or recycled admixtures, reuse of waste to produce mineral products and fertilisers [30]. Another major area in waste management is the use of mineral waste generated by mineral extraction industries [31, p. 7].

The problem of air pollution gains special significance in relation to the prospects of cross-border carbon regulation in the EU in relation to imported goods. Undoubtedly, the international energy market is now fiercely competitive. Stricter environmental laws and regulations are turning into an instrument of competition. In the light of decarbonisation, in order to maintain their competitive edge, national economies need to undergo a structural transformation to enhance their efficiency and at the same to reduce their carbon footprint. This task is closely related to technological development, innovation and organisational and institutional aspects of technological modernisation and re-equipment. The sectors that will be most affected by the structural transformation are not only those that will be directly targeted by

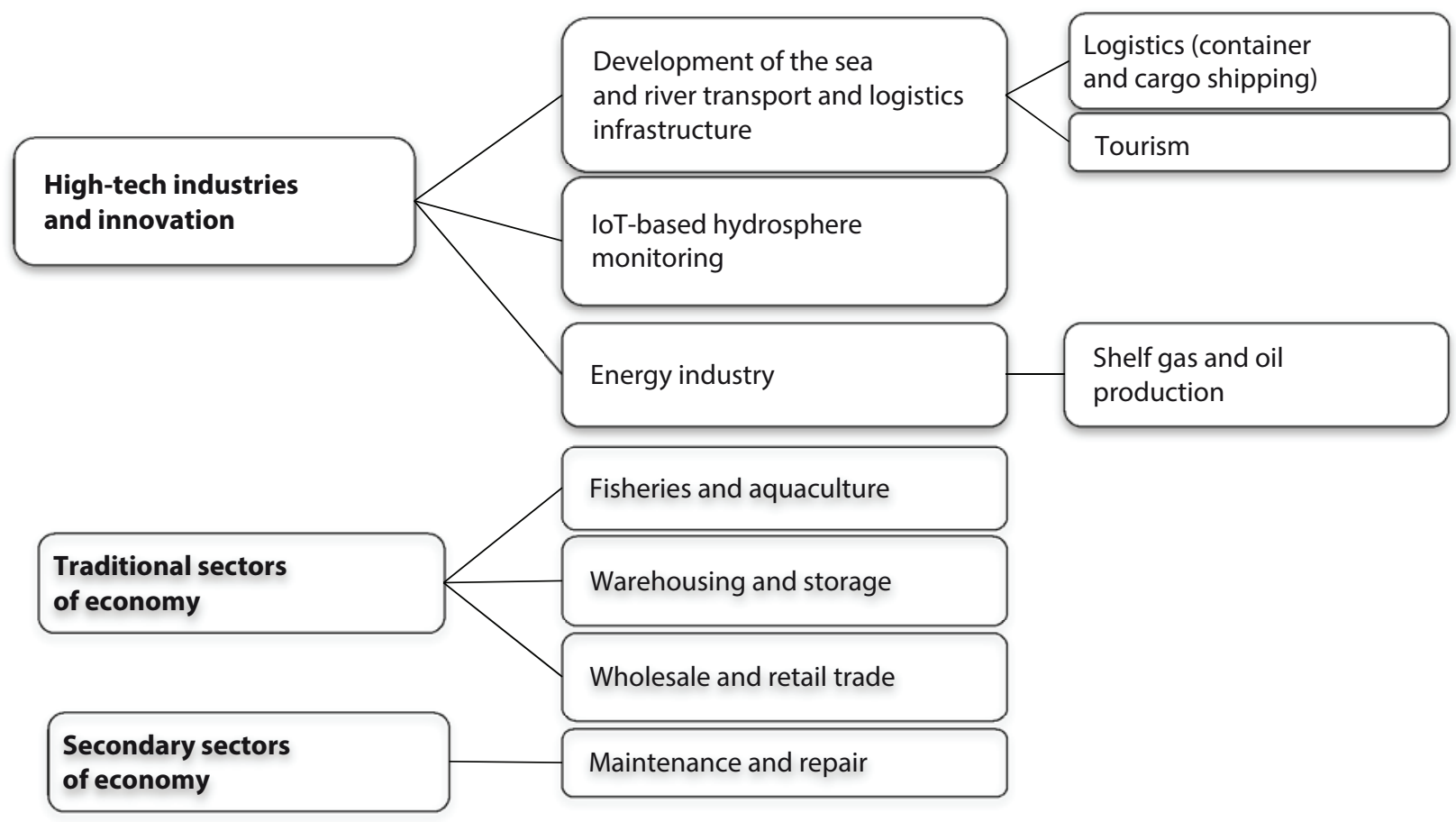

Fig. 12. Classification of the areas of blue economy development in Russia 
cross-border carbon regulation (metallurgy, oil and gas production, etc.) but also machine-building, instrument engineering (e.g. production of environmental monitoring solutions), transport, forestry, agriculture and finance. Another task that is gaining popularity is the economic evaluation of the potential of carbon capture utilisation and storage systems (CCUS). Moreover, it is necessary to ensure that regional enterprises are well prepared for the introduction of an emission trading system in the industrial sector.

In Russia, the problems of industrial water pollution feature high on the environmental agenda. Much attention is given to the development of fisheries and aquaculture. The most preferable areas are those that provide opportunities for the innovative application of technological solutions (see Fig. 12).

For the Urals, the area that holds most promise lies in the development of the Internet of Things (IoT) monitoring. Environmental monitoring is a knowledge-intensive sphere directly related to the aerospace and IT industries. Environmental monitoring involving IoT solutions will enable the authorities to collect and analyse data for a wide range of purposes, including improved resource conservation and disaster prevention.

\section{Conclusion}

The sustainable development concept underpins the global framework for solving environmental and social issues. It has become pivotal for environmental, social and economic policy-making in many countries of the world. Recently, there has been a dramatic surge of interest of government agencies, businesses and academic communities in the issues of sustainability.

Sustainable development implies the use of efficient knowledge-based management tools [32], which, in its turn, determines the need for a more in-depth analysis of the theoretical framework underpinning the sustainability concept. Our analysis of the main theoretical approaches to this problem has shown that, despite the persistent scholarly interest, the solutions proposed by different schools of economic thought mostly revolve around these schools' own dogmata. Some of these schools are also prone to unfounded techno-optimism and to unrealistic expectations regarding the possibility of promoting social prosperity by reducing consumption. We believe that it would be more productive to combine theoretical and practical approaches and conduct experimental studies in order to find the most efficient ways of advancing sustainable development.

Analysis of the eco-intensity of Ural regions has brought to light the lack of interest that local businesses have in using sustainable practices and technologies. Our analysis of the key practice-oriented concepts within the SDGs framework, in particular the concepts of green and blue economy, has led us to identify the areas of sustainable development that hold the most promise in the Russian context.

The concept of sustainable development undoubtedly embodies a universal call to pursue responsible innovation for a green future. The above-described priority areas that guide the implementation of the green economy are in one way or another connected to technological development, which creates the need for more consistent and purposeful action in the sphere of $R \& D$, innovation, and intellectual property protection.

Our research findings may be used by policy-makers who devise regional sustainable development strategies. They may also be of interest to other researchers studying the theoretical and practical aspects of socio-environmental and economic sustainability.

\section{References}

1. Kurochkina, A. A. \& Semenova, Y. E. (2020). Economic transformations in the context of greening the economy. In: Sovremennyye problemy gidrometeorologii i monitoringa okruzhayushchey sredy v prostranstve SNG. Sbornik tesisov Mezhdunarodnoy nauchno-prakticheskoy konferentsii, posvyashchennoy 90-letiyu rossiyskogo gosudarstvennogo gidrometeorologicheskogo universiteta [Modern Problems of Hydrometeorology and Environmental Monitoring in the CIS. Collection of theses of the International Scientific and Practical Conference dedicated to the 90th anniversary of the Russian State Hydrometeorological University] (pp. 675-677). St. Petersburg: Russian State Hydrometeorological University. (In Russ.)

2. Bakushev, V. V., Ponedelkov, A. V. \& Moiseev, V. N. (2016). “The Sustainable Development with the Private Sector» World Goal-Setting for Business and Politicians to 2030. Nauka i obrazovanie: khozyaystvo i ekonomika; predprinimatelstvo; pravo i upravlenie [Science and education: economy and financial economy; entrepreneurship; law and management], 4, 40-44. (In Russ.)

3. Novak, K. \& Zaitseva, N. (2015). Sustainability turnover. BRICS Business magazine, 1. Retrieved from: https:// bricsmagazine.com/ru/articles/perevorot-ustoychivosti (Date of access: 01.07.2021). (In Russ.)

4. Meadows, D. H., Meadows, D. L., Randers, J. \& Behrens, W. W. (1972). The Limits to Growth. New York: Universal Books, 205. 
5. Phillimore, J. (2001). Schumpeter, Schumacher and the greening of technology. Technology Analysis \& Strategic Management, 13(1), 23-37. DOI: 101080/09537320120040428.

6. Mathews, J. A. (2020). Schumpeterian economic dynamics of greening: propagation of green eco-platforms. Journal of Evolutionary Economics, 30(4), 929-948. DOI: 10.1007/s00191-020-00669-5.

7. Shrivastava, M. K. (2009). Towards a green techno-economic paradigm. Journal of Resources, Energy and Development, 6(2), 67-80. DOI: 10.3233/RED-120060.

8. Jacobs, M. (1997). Sustainability and markets: On the neoclassical model of environmental economics. New Political Economy, 2(3), 365-385. DOI: 10.1080/13563469708406313

9. Courvisanos, J. (2005). A post-Keynesian innovation policy for sustainable development. International Journal of Environment, Workplace and Employment, 1(2), 187-202. DOI: 10.1504/IJEWE.2005.006384.

10. Dafermos, Y. \& Nikolaidi, M. (2019). Fiscal policy and ecological sustainability: a post-Keynesian perspective. In: Frontiers of heterodox macroeconomics (pp. 277-322). Palgrave Macmillan, Cham. DOI: 10.1007/978-3-030-23929-9_7

11. Holt, R. P. (2005). Post-Keynesian economics and sustainable development. International Journal of Environment, Workplace and Employment, 1(2), 174-186. DOI: 10.1504/IJEWE.2005.006383.

12. Fontana, G. \& Sawyer, M. (2013). Post-Keynesian and Kaleckian thoughts on ecological macroeconomics. European Journal of Economics and Economic Policies: Intervention, 10(2), 256-267. DOI: 10.4337/ejeep.2013.02.09.

13. Blackwater, B. (2012). Two cheers for environmental Keynesianism. Capitalism Nature Socialism, 23(2), 51-74. DOI: $10.1080 / 10455752.2012 .675232$

14. Costanza, R. (2020). Valuing natural capital and ecosystem services toward the goals of efficiency, fairness, and sustainability. Ecosystem Services, 43, 101096. DOI: 10.1016/j.ecoser.2020.101096.

15. Antropov, V. A., Bochko, V. S. \& Kniss, M. Y. (2018). Development of the «green» economy in Russia. Vestnik Uralskogo gosudarstvennogo universiteta putey soobshcheniya [Herald of the Ural State University of Railway Transport], 3, 68-83. DOI: 10.20291/2079-0392-2018-3-68-83. (In Russ.)

16. Bochko, V. S. (2017). Green Economy: awareness of the phenomenon, taking into account the problems of the regional level. In: Materialy IV vserossiyskogo simpoziuma po regionalnoy ekonomike [Materials of the IV All-Russian Symposium on Regional Economics] (pp. 13-17). Ekaterinburg: Institute of Economics UB RAS. (In Russ.)

17. Pakhomova, N. V., Richter, K. K. \& Vetrova, M. A. (2017). Circular economy as challenge to the fourth industrial revolution. Innovatsii [Innovations], 7(225), 66-70. (In Russ.)

18. Richter, K. K. \& Vetrova, M. A. (2017). Adoption of operational decisions in the transition to the principles of the circular economy in Russian industry. In: Ekologo-ekonomicheskie problemy razvitiya regionovi stran (ustoychivoe razvitie, upravlenie, prirodopolzovanie). Materialy 14-y Mezhdunarodnoy nauchno-prakticheskoy konferentsii Rossiyskogo obshchestva ekologicheskoy ekonomiki ["Ecological and economic problems of development of regions and countries (sustainable development, management of natural resources)" Of the Proceedings 14th International Conference of the Russian Society for Ecological Economics)] (pp. 229-234). Petrozavodsk: Karelian Research Centre of RAS. (In Russ.)

19. Valko, D. V. (2020). Circular Economy: Basic Business Models and Economic Opportunities. Zhurnal Economicheskoy Teorii [Russian Journal of Economic Theory], 17(1), 156-163. DOI: 10.31063/2073-6517/2020.17-1.12. (In Russ.)

20. Mirzekhanova, Z. G. (2020). Implementing the Green Economy Concepts in the Russian Far East: Environmental Preconditions. Ekonomika regiona [Economy of Region], 16(2), 449-463. DOI: 10.17059/2020-2-9. (In Russ.)

21. Yakovlev, I. A., Kabir, L. S. \& Nikulina, S. I. (2020 Climate Policy of the Russian Federation: International Cooperation and National Approach. Finansovyy zhurnal [Financial Journal], 12(4), 26-36. DOI: 10.31107/2075-1990-2020-4-26-36 (In Russ.)

22. Kabir L. S. (2019). State support for «green» investments and market «green» financing: foreign experience. Innovatika i ekspertiza: nauchnye trudy [Innovatics and Expert Examination], 1(26), 97-108. DOI: 10.35264/1996-2274-2019-1-97108. (In Russ.).

23. Porfiriev, B. N. (2012). Green economy: new trends and directions of the world economic development. In: Nauchnye trudy: Institut narodnokhozyaystvennogo prognozirovaniya RAN ["Scientific Articles - Institute of Economic Forecasting Russian Academy of Sciences], 10, 9-33. Retrieved from: http://www.ecfor.ru/pdf.php?id=books/sa2012/02 C. 10. (Date of access: 11.05.2021). (In Russ.)

24. Le Blanc, D., Freire, C. \& Vierros, M. (2017). Mapping the linkages between oceans and other Sustainable Development Goals: A preliminary exploration. Department of Economic \& Social Affairs (No. 149). DESA Working Paper. Retrieved from: https://sustainabledevelopment.un.org/content/documents/12468DESA_WP149_E.pdf (Date of access: 14.04.2021).

25. Lee, K. H., Noh, J. \& Khim, J. S. (2020). The Blue Economy and the United Nations' sustainable development goals: Challenges and opportunities. Environment international, 137, 105528. DOI: 10.1016/j.envint.2020.105528.

26. Kudelas, D., Domru, E., Stoianov, A. \& Peters, D. (2018). International Experience, Principles and Conditions for the Transition to a "Green Economy". E3S Web of Conferences, 41, 04023. EDP Sciences. Retrieved from: https://www. researchgate.net/publication/325991139_International_Experience_Principles_and_Conditions_for_the_Transition_to_a_ Green_Economy (Date of access: 15.05.2021) DOI: 10.1051/e3sconf/20184104023.

27. Dyakov, M. Yu. (2015). Kamchatka's economy eco-intensity as an indicator of the transition to environmental and economic balance. EKO [ECO], 12(498), 154-164.

28. Lavrikova, Yu. G. \& Malysh, E. V. (2014). The green economy in cluster development. Vestnik UrFU. Seriya: Ekonomika i upravleniye [Bulletin of Ural federal university. Series economics and management], 3, 120-133. (In Russ.) 
29. Lottermoser, B. G. (2011). Recycling, reuse and rehabilitation of mine wastes. Elements, 7(6), 405-410.

30. Guman, O. \& Wegner-Kozlova, E. (2020). Waste management based on circular economy principles. E3S Web of Conferences, 177, 04014. Retrieved from: https://www.e3s-conferences.org/articles/e3sconf/pdf/2020/37/e3sconf_ umd2020_04014.pdf. (Date of access: 15.05.2021) DOI: 10.1051/e3sconf/202017704014.

31. Perepelitsyn, V. A., Rytvin, V. M., Koroteev, V. A., Makarov, A. B., Grigoriev, V. G., Gilvarg, S. I., ... Tabulovich, F. A. (2013). Tekhnogennoe mineralnoe syre Urala [Industrial mineral raw materials of Ural mountains]. Ekaterinburg: UB RAS, 332. (In Russ.)

32. Bringezu, S., Potočnik, J., Schandl, H., Lu, Y., Ramaswami, A., Swilling, M., \& Suh, S. (2016). Multi-scale governance of sustainable natural resource use-challenges and opportunities for monitoring and institutional development at the national and global level. Sustainability, 8(8), 778. DOI: 10.3390/su8080778.

\section{About the Authors}

Yuliya G. Lavrikova - Dr. Sci. (Econ.), Associate Professor, Director, Institute of Economics of the Ural Branch of RAS; Scopus Author ID: 57190430359; http://orcid.org/0000-0002-6419-2561 (29, Moskovskaya St., Ekaterinburg, 620014, Russian Federation; e-mail: lavrikova.ug@uiec.ru).

Olga N. Buchinskaia - Cand. Sci. (Econ.), Senior Research Associate of the Sector of Territorial Competition of the Center for Economic Theory, Institute of Economics of the Ural Branch of RAS; Financial Research Institute of the Ministry of Finance of the Russian Federation; https://orcid.org/0000-0002-5421-2522 (29, Moskovskaya St., Ekaterinburg, 620014; 3/2, Nastasyinskiy Lane, Moscow, 127006, Russian Federation; e-mail: buchinskaia.on@uiec.ru).

Ekaterina O. Wegner-Kozlova - Cand. Sci. (Econ.), Senior Researcher of the Center for Structural Policy of Region, Institute of Economics of the Ural Branch of RAS; Financial Research Institute of the Ministry of Finance of the Russian Federation; https://orcid.org/0000-0003-4182-6514 (29, Moskovskaya St., Ekaterinburg, 620014; 3/2, Nastasyinskiy Lane, Moscow, 127006, Russian Federation; e-mail: vegner.kozlova.eo@uiec.ru).

\section{Информация об авторах}

Лаврикова Юлия Георгиевна - доктор экономических наук, доцент, директор, Институт экономики УрО PAH; Scopus Author ID: 57190430359; https://orcid.org/0000-0002-6419-2561 (Российская Федерация, 620014, г. Екатеринбург, ул. Московская, 29; e-mail: lavrikova.ug@uiec.ru).

Бучинская Ольга Николаевна - кандидат экономических наук, старший научный сотрудник Сектора территориальной конкуренции Центра экономической теории, Институт экономики УрО РАН; Научно-исследовательский финансовый институт Минфина России; https://orcid.org/0000-0002-5421-2522 (Российская Федерация, 620014, г. Екатеринбург, ул. Московская, 29; 127006, г. Москва Настасьинский пер., 3, стр. 2; e-mail: buchinskaia.on@uiec.ru).

Вегнер-Козлова Екатерина Олеговна - кандидат экономических наук, старший научный сотрудник Центра структурной политики региона Института экономики УрО РАН; Научно-исследовательский финансовый институт Минфина России; https://orcid.org/0000-0003-4182-6514 (Российская Федерация, 620014, г. Екатеринбург, ул. Московская, 29; 127006, г. Москва, Настасьинский пер., 3, стр. 2; e-mail: vegner.kozlova.eo@uiec.ru).

Дата поступления рукописи: 09.07.21

Прошла рецензирование: 14.08 .21

Принято решение о публикации: 24.09.2021.

Received: 09 Jul 2021.

Reviewed: 14 Aug 2021.

Accepted: 24 Sep 2021. 